\title{
Self-efficacy, Adaptability and Intention of Searching for Vocational Guidance in Adolescents $^{1}$
}

\author{
Rodolfo Augusto Matteo Ambiel², Thaline da Cunha Moreira², Dianniffer Aparecida Oliveira², \\ Edson Cardoso Pereira², Débora Noemi Hernandez ${ }^{2}$ \\ ${ }^{2}$ Universidade São Francisco, Campinas-SP, Brazil
}

\begin{abstract}
Vocational guidance (VG) involves several variables that can help the individual to make a professional choice and build his or her career. The purpose of this study was to analyze the relationship between self-efficacy for professional choice and career adaptability in high school students, as well as to verify possible differences regarding the intention or not to participate in a VG process. 272 students participated in this study, from a public school, aged between 14 and 19 years, 51.5\% female. A Sociodemographic Questionnaire, the Self-efficacy Scale for Professional Choice (EAE-EP) and the Career Adapt-Abilities Scale (CAAS-Brazil) were applied. From the Pearson correlation analysis, ANOVA and Cohen's d, the results indicated positive correlations between the constructs, in addition, it was observed the difference between the students who would like or not to undergo a VG process. Implications for the practice are discussed.
\end{abstract}

Keywords: self-efficacy, professional development, professional choice, high school

\section{Autoeficácia, Adaptabilidade e Intenção de Busca de Orientação Profissional em Adolescentes}

\begin{abstract}
Resumo: A orientação profissional (OP) envolve diversas variáveis que podem auxiliar o indivíduo a realizar uma escolha profissional e construir sua carreira. O objetivo desse estudo foi analisar a relação entre a autoeficácia para escolha profissional e a adaptabilidade de carreira em estudantes do ensino médio, além de verificar possíveis diferenças quanto à intenção ou não em participar de um processo de OP. Participaram 272 alunos, de uma escola pública, com idade entre 14 e 19 anos, sendo 51,5\% do sexo feminino. Foram aplicados um Questionário sociodemográfico, a Escala de Autoeficácia para Escolha Profissional (EAE-EP) e a Career Adapt-Abilities Scale (CAAS-Brasil). A partir das análises de correlação de Pearson, ANOVA e d de Cohen, os resultados indicaram correlações positivas entre os construtos, além disso, foi observada a diferença entre os alunos que gostariam ou não de passar por um processo de OP. As implicações para a prática são discutidas.
\end{abstract}

Palavras-chave: autoeficácia, desenvolvimento profissional, escolha profissional, ensino médio

\section{Autoeficacia, Adaptabilidad e Intención de Búsqueda de Orientación Profesional en Adolescentes}

\begin{abstract}
Resumen: La orientación profesional (OP) engloba diversas variables que pueden ayudar al individuo a realizar una elección profesional y construir su carrera. El objetivo de este estudio fue analizar la relación entre la autoeficacia para elección profesional y la adaptabilidad de carrera en estudiantes de enseñanza secundaria, además de verificar posibles diferencias en cuanto a la intención o no de participar en un proceso de OP. En este estudio participaron 272 alumnos, de una escuela pública, con edad entre 14 y 19 años, siendo el 51,5\% del sexo femenino. Se aplicó un Cuestionario sociodemográfico, la Escala de Autoeficacia para Elección Profesional (EAE-EP) y la Career Adapt-Abilities Scale (CAAS-Brasil). A partir de los análisis de correlación de Pearson, ANOVA y d de Cohen, los resultados indicaron correlaciones positivas entre los constructos, además, se observó la diferencia entre los alumnos que quisieran o no pasar por un proceso de OP. Las implicaciones para la práctica se discuten.
\end{abstract}

Palabras clave: autoeficacia, desarrollo profesional, elección profesional, enseñanza secundaria

\footnotetext{
${ }^{1}$ This study was financed in part by the Coordenação de Aperfeiçoamento de Pessoal de Nível Superior - Brasil (CAPES) - Finance Code 001.

Correspondence address: Thaline da Cunha Moreira. Universidade São Francisco. Rua Waldemar César da Silveira, 105, Jardim Cura D'Ars, Campinas-SP, Brazil. CEP 13.045-510. E-mail: thacmoreira@gmail.com
}

Vocational Guidance (VG) is considered a process of facilitating decision making at specific moments in an individual's professional trajectory and has historically been characterized using psychological instruments (Ambiel, 2016). 
According to the determinations of CFP Resolution No. 07/2003 of the Federal Counsel of Psychology (2003), psychological evaluation should be performed based on consistent theoretical and practical knowledge, with the aim of providing an understanding of the personal, social and psychological factors of the individual.

Psychological evaluation aims at the study and interpretation of information about the individual and society, including, evaluates in a procedural way the functioning of someone. Thus, at the Brazilian level, it is important to reflect on its use in the VG, emphasizing not only the practice, technique and instruments, but also the improvement of the counselor adviser to carry out this work (Ambiel, 2016). In other words, it is urgent to demystify vocational guidance as only the application of a vocational test, if the professional needs to appropriate the knowledge about the constructs that are studied in the area, analyze the conditions of the person and verify the relevant instruments to the individual in the process of choice (Pasian, Melo-Silva, \& Okino, 2015).

Regarding the constructs evaluated in a VG process, a concept that has been explored is that of self-efficacy, which refers to people's beliefs in their ability to organize and perform certain actions (Bandura, 1977). Self-efficacy studies provide professionals with contributions to the development of interventions in those who are in the process of career decision making, since a low perception of their competencies may affect the performance of specific activities and even decision making (Ambiel, 2016; Lent, Brown, \& Hackett, 1994).

The concept was presented by Bandura (1977) as the central point of the Cognitive Social Theory (CST), in which the individual is understood as the agent of his or her actions, being self-reflexive, self-organized, self-regulated and proactive. Thus, in the design of CST, internal personal factors (for example, beliefs), behaviors and environment interact in a dynamic and continuous way, in the so-called triadic reciprocity, and thus the way in which the person interprets certain stimuli can modify his or her own behavior that, in turn, can change the surrounding environment (Pajares \& Olaz, 2008). It should be noted that self-efficacy beliefs can be applied to different situations and domains of performance, such as in the career context (Betz \& Luzzo, 1996; Lent et al., 1994).

In this context, Hackett and Betz (1981) were the pioneer authors who verified the relationship between selfefficacy beliefs and professional choices in female students, thus contributing to Taylor and Betz (1983) later submitting an instrument to assess people's confidence to perform career decision-making activities, which was called the Career Decision-Making Self-Efficacy Scale (CDMSES). The term career decision-making self-efficacy, as used for standardization purposes, in this article refers to people's beliefs about their ability to engage in professional decisionmaking (Ambiel \& Noronha, 2012). Moving forward in relation to the previous proposal and integrating self-efficacy with other CST concepts, Lent et al. (1994) the Cognitive Social Theory of Career Development (CSTCD).
In the Brazilian context, self-efficacy for professional choice was investigated by Ambiel and Noronha (2012), who constructed an instrument to evaluate this construct in high school students. The Self-efficacy Scale for Professional Choice (Portuguese acronym: EAE-EP) is formed by four factors that were elaborated based on the maturity model of Crites and in the CDMSES, being self-efficacy for selfevaluation, for collecting occupational information, for seeking professional information practice and for future planning, as well as a general score.

Some studies have already been carried out with EAEEP demonstrating its relation with positive and negative affections (Noronha, Freitas, Piovezan, \& Azevedo, 2013), with family support and parental styles (Ventura \& Noronha, 2014; Ambiel \& Noronha, 2016), with indecision and vocational exploration (Ambiel \& Hernandéz, 2016), as well as evaluating their psychometric properties through the Rasch-Andrich model, in which the results showed the one-dimensional way of each one of the four factors, with their respective items adjusted to the model, and also that the items tended to be easily endorsed by the sample (Ambiel, Noronha, \& Carvalho, 2015).

In this way, the presentation of these studies with high school students allows us to explore some issues related to self-regulation competences that are strictly linked to the process of professional choice of adolescents, in which beliefs of self-efficacy seem to be important (Chiesa, Massei, \& Guglielmi, 2016). However, career adaptability has also been studied as a regulatory variable, mediating between individual dispositions and decision-making behaviors per se (Rossier, 2015), positive correlations were also found between self-efficacy and adaptability (Ambiel, 2014; Fan, 2016; van Vianen, Klehe, Koen, \& Dries, 2012).

The term career adaptability, although first used by Super and Knasel (1981), was further explored by Savickas (1997), understood as the readiness of a person to deal with professional transitions such as job changes and personal traumas. This construct is presented as a psychosocial attribute, considering that both personal and environmental aspects favor its development (Rossier, 2015; Savickas \& Porfeli, 2012).

The career adaptability can be analyzed through four dimensions, which seek to measure some behaviors of individuals and the resources that can be used by them. The first dimension called Concern refers to the individual's ability to think about his or her career and to plan his or her professional future, preparing for possible challenges; the second dimension called Control, refers to the responsibility of the person about his or her professional life, presenting behaviors as, effort, persistence, among others; the third dimension Curiosity refers to the behavior of exploring oneself and other contexts, placing oneself in various situations and roles; and finally, the Confidence dimension, referring to people's belief in his or her ability to make choices, to analyze their plans, as well as to recognize and execute their aspiration (Ginevra, Pallini, Vecchio, Nota, \& Soresi, 2016; Savickas \& Porfeli, 2012). 
In this perspective, Savickas and Porfeli (2012) proposed the construction of a measure of career adaptability with the participation of vocational psychologists from 13 countries, which resulted in the Career Adapt-Abilities Scale (CAAS). This instrument seeks to assess the skills to adapt, using resources and strategies to manage the critical tasks of career transition, through four factors that refer to the dimensions of career adaptability, previously mentioned. The results obtained in the construction of the international CAAS suggest that the scale measures the construct in the same way in all the countries studied, being considered accurate, with Cronbach's alpha varying between 0.87 and 0.96 . In a short time, several studies were conducted in several countries, and Rudolph, Lavigne and Zacher (2017) conducted a meta-analysis that included 90 studies. Among the several findings, it is worth noting that the average correlation between career adaptability and self-efficacy for professional choice was 0.65 , in samples predominantly from university students.

In Brazil, Teixeira, Bardagi, Lassance, Magalhães and Duarte (2012) investigated the psychometric properties of CAAS, composed of 22 items, which were elaborated from the Portuguese version. The results presented adequate adjustments and according to the international CAAS. After the publication of the CAAS-Brazil, it continued to be the subject of some revisions and adjustments that culminated in its most current format, with 24 items distributed in four factors that represent the dimensions of career adaptability, presenting reliability through Cronbach's alpha, which varied between 0.83 and 0.89 (Audibert \& Teixeira, 2015).

Still in the Brazilian context, Zacher, Ambiel and Noronha (2015), studying a sample of adult workers, found that high levels of career adaptability predicted low career entrenchment. In another study, Ambiel, Carvalho, Martins and Tofoli (2016) sought to investigate the differences between adolescents and adults in CAAS. The results showed that the factorial structure with the sample of adolescents was the same for adults. As for the difference between the samples, the adults scored higher than the adolescents on all factors. Despite this, there is no psychometric evidence to support the need for different versions of CAAS for each of these groups.

Therefore, it can be understood that self-efficacy for professional choice and career adaptability are related variables and that, when present at an adequate level in a person's functioning, tend to facilitate decision making and deal with changes and transitions during the career, as well as being predictors of better job search strategies (Guan et al., 2013). Thus, a hypothesis of this study is that positive correlations between the instruments are found, with magnitudes close to what the international literature points out (Rudolph et al., 2017).

However, while research has helped to understand the competencies and beliefs that can assist people in decisionmaking and career transition processes, and advocates for vocational guidance as a facilitator of such a process, the literature does not yet clarify why people to seek such a service. There are reports of the importance of the therapeutic alliance in the success of counseling (Masdonati, Perdrix, Massoudi, \& Roussier, 2013; Whiston, Rossier, \& Barón, 2015) and favorable outcomes of the interventions (Cardoso, Silva, Gonçalves, \& Duarte, 2014; Di Fabio, 2016; Maree, 2015), but the identification of the determinants of search for vocational guidance is still scarce.

In Brazil, two old studies, with the objective of identifying VG demands with high school students were recovered. Araújo (2003) studied students of a private school and identified that they showed a desire to obtain help for professional choice, while Ribeiro (2003), in a study with students of a public school, reports that the main demands were related to have more information about entering the job market, real possibilities of insertion and the real availability of job offers.

Thus, there are few studies that seek to answer the question: what psychological characteristics distinguish students who say they need to undergo VG intervention from those who do not report this need? Although there are several possibilities of traits and other characteristics to answer such question, in this study we chose to adopt career adaptability and self-efficacy for professional choice, since both are understood as variables involved in the choice process (Rossier, 2015) and that there is evidence in the foreign context that both are related variables (Rudolph et al., 2017). Thus, the second hypothesis of this study is that there is a significant difference, with medium (at least) effect sizes between the groups that say they need to do VG and those who say they do not need it.

By these meanings, self-efficacy for career choice and career adaptability may be constructs relevant to the vocational guidance process. Thus, the present article aims to verify the relationship between self-efficacy and career adaptability in a sample of high school students and also to investigate possible differences in the constructs between the groups of students formed from the intention or not to participate in a VG process.

\section{Method}

\section{Participants}

The sample consisted of 272 adolescents aged 14 to 19 years $(M=16.34, S D=0.99), 52 \%$ female and $48 \%$ male. Participants attended high school in a public school in the interior of the state of São Paulo, accounting for $36.6 \%$ in the first year, $32.1 \%$ in the second year and $31.3 \%$ in the third year.

\section{Instruments}

Sociodemographic Questionnaire. The Sociodemographic Questionnaire was used to gather information about the personal, family and socioeconomic characteristics of 
the participants. It also contains a question about the adolescents' interest in participating in a VG process, for that, a small informed text has been inserted, which is what the process is about. By means of three affirmations the students should select the one that best represented him or her, with that after the data collection the students were divided into three groups. The statements were as follows: "I would not seek vocational guidance, because I am already sure of what I want to do in the future", representing Group 1 (G1); "Although I already know what I want to do in the future, I would do a vocational guidance, because it could help me to be sure I'm on the right track", forming Group 2 (G2); and "I would seek vocational guidance, as I have no idea what I'm going to do next year" as part of Group 3 (G3).

Self-efficacy Scale for Professional Choice (EAE$E P)$. The Self-efficacy Scale for Professional Choice (EAE-EP) by Ambiel and Noronha (2012) aims to evaluate individuals' beliefs in their ability to engage in activities related to professional choice. EAE-EP has 47 items, with a response key on a four-point Likert scale, being 1 "little" and 4 "very". The instrument is composed of four factors named as self-efficacy for: Self-assessment, Occupational Information Collection, Search for Professional Practical Information and Future Planning, in addition to a general score. The precision of the scale is presented by Cronbach's alpha coefficient, ranging from 0.79 to 0.88 for the factors and 0.94 for the general score, demonstrating that the instrument has adequate psychometric properties.

Career Adapt-Abilities Scale (CAAS-Brasil). The CAAS is an instrument constructed in English by a group of vocational psychologists, so that it could be translated later to the other countries. CAAS-Brazil was translated and presented by Teixeira et al. (2012) with the objective of evaluating individuals' abilities to adapt and manage critical tasks of transitions throughout the process of building their careers. In this study, the version validated by Audibert and Teixeira (2015) was used, composed of 24 items, with a five-point Likert type response key, items are distributed into four factors, namely concern, control, curiosity, and confidence. The results of the confirmatory factor analysis revealed that the international CAAS structure was also applied to the Brazilian sample, with precision indexes ranging from 0.76 to 0.82 for the factors and 0.91 for the general scorew.

\section{Procedure}

Data collection. Regarding the organization of the collection, only the students who delivered the Free and Informed Consent Term (FICF) signed by the person responsible or himself/herself when they were over 18 years of age participated in the research. First, the sociodemographic questionnaire was applied, followed by the EAE-EP, followed by the CAAS. The collection was carried out in a classroom, collectively, with a duration of approximately 30 minutes.

Data analysis. The data were tabulated in an electronic spreadsheet and analyzed using the statistical software SPSS v.20. Missing cases were excluded from the database. At first Pearson's analysis was performed to evaluate the correlations between the instruments, then, to verify the differences between the groups, an analysis of variance (ANOVA) was performed using Tukey's post hoc test in addition to Cohen's $\mathrm{d}$ to know the size of the effect of the differences, as indicated by Dancey and Reidy (2006).

\section{Ethical Considerations}

In relation to the previous reports, the contact with the school that accepted to participate in the research was initially carried out, after the approval of the institution to carry out the present study, the project was submitted to the Research Ethics Committee (Portuguese acronym: CEP) of the Universidade São Francisco, being approved (CAAE: 36058614.5.0000.5514). It should be noted that all the ethical care required in conducting research with human beings was considered during the process.

\section{Results}

To reach the proposed objectives, three types of analysis were performed: Pearson correlation, analysis of variance (ANOVA) and effect sizes of differences, according to Cohen's d. The magnitudes of the correlations are interpreted as indicated by Dancey and Reidy (2006), being considered low $(0.0-0.3)$, moderate $(0.4-0.6)$ and high $(0.7-0,9)$ and as to the size of the effect, it was analyzed by means of Cohen's $d$, considered according to the respective authors as small $(0,0-$ $0,20)$, medium $(0,21-0,79)$ and large $(0.80-1)$. Table 1 shows the correlations between the EAE-EP and CAAS factors.

Table 1

Correlation between EAE-EP and CAAS factors

\begin{tabular}{cccccc} 
& \multicolumn{4}{c}{ CAAS } \\
\cline { 2 - 6 } & & Concern & Control & Curiosity & Confidence \\
\cline { 2 - 6 } EAE-EP & SA & $0.56^{* *}$ & $0.54^{* *}$ & $0.50^{* *}$ & $0.54^{* *}$ \\
& COI & $0.49^{* *}$ & $0.41^{* *}$ & $0.43^{* *}$ & $0.41^{* *}$ \\
& SPI & $0.48^{* *}$ & $0.39^{* *}$ & $0.49^{* *}$ & $0.40^{* *}$ \\
& FP & $0.47^{* *}$ & $0.40^{* *}$ & $0.42^{* *}$ & $0.46^{* *}$ \\
\hline
\end{tabular}

Note. $\mathrm{SA}=$ self-assessment; $\mathrm{COI}=$ Collecting Occupational Information; SPPI $=$ Search for Professional Practical Information; FP $=$ Future Planning; $* *=p \leq 0.01$ 
According to Table 1 , among the 16 possible correlations, all were positive, significant and with moderate magnitudes ranging from 0.39 to 0.56 . It can be noted that the EAE-EP self-assessment factor presented the largest magnitudes with the CAAS dimensions, being the most expressive with the dimension Concern.

The sample was then divided into three groups, according to the question that sought to know the interest of adolescents in participating in a VG process. The G1 was formed by those who did not show interest in the VG $(n=48)$ and $\mathrm{G} 2$ and G3 integrating the students who were interested, and in $\mathrm{G} 2(n=170)$ they had already made a choice for the next year and in G3 $(n=44)$ had not yet decided about the future. To verify the differences between the groups, a variance analysis (ANOVA) was performed using Tukey's post hoc test, in addition to Cohen's d to know the size of the effect of the differences. Table 2 presents this information.

Table 2

ANOVA, Tukey and Cohen's $d-E A E-E P$ and CAAS factors

\begin{tabular}{|c|c|c|c|c|c|c|c|c|}
\hline & \multicolumn{4}{|c|}{ EAE-EP } & \multicolumn{4}{|c|}{ CAAS } \\
\hline & SA & COI & SPPI & FP & Conc. & Con. & Cur. & Conf. \\
\hline $\mathrm{gl}$ & 2 & 2 & 2 & 2 & 2 & 2 & 2 & 2 \\
\hline $\mathrm{F}$ & 14.300 & 10.406 & 7.842 & 5.310 & 7.430 & 4.660 & 1.616 & 1.074 \\
\hline$p$ & 0.000 & 0.000 & 0.000 & 0.005 & 0.001 & 0.010 & 0.201 & 0.343 \\
\hline Tukey & $\mathrm{G} 3<\mathrm{G} 1, \mathrm{G} 2$ & $\mathrm{G} 3<\mathrm{G} 2$ & $\mathrm{G} 3<\mathrm{G} 2$ & - & $\mathrm{G} 3<\mathrm{G} 1, \mathrm{G} 2$ & $\mathrm{G} 3<\mathrm{G} 1$ & - & - \\
\hline $\mathrm{d}$ & $\begin{array}{l}\mathrm{d}_{\mathrm{G} 1 * \mathrm{G} 2}=-0.06 \\
\mathrm{~d}_{\mathrm{G} 1 * \mathrm{G} 3}=-0.86 \\
\mathrm{~d}_{\mathrm{G} 2 * \mathrm{G} 3}=-0.87\end{array}$ & $\begin{array}{l}\mathrm{d}_{\mathrm{G} 1 * \mathrm{G} 2}=0.26 \\
\mathrm{~d}_{\mathrm{G} 1 * \mathrm{G} 3}=-0.46 \\
\mathrm{~d}_{\mathrm{G} 2 * \mathrm{G} 3}=-0.79\end{array}$ & $\begin{array}{l}\mathrm{d}_{\mathrm{G} 1 * \mathrm{G} 2}=0.15 \\
\mathrm{~d}_{\mathrm{G} 1 * \mathrm{G} 3}=-0.53 \\
\mathrm{~d}_{\mathrm{G} 2 * \mathrm{G} 3}=-0.68\end{array}$ & $\begin{array}{l}\mathrm{d}_{\mathrm{G} 1 * \mathrm{G} 2}=0.24 \\
\mathrm{~d}_{\mathrm{G} 1 * \mathrm{G} 3}=-0.27 \\
\mathrm{~d}_{\mathrm{G} 2 * \mathrm{G} 3}=-0.55\end{array}$ & $\begin{array}{c}\mathrm{d}_{\mathrm{G} 1 * \mathrm{G} 2}=0.02 \\
\mathrm{~d}_{\mathrm{G} 1 * \mathrm{G} 3}=-0.53 \\
\mathrm{~d}_{\mathrm{G} 2 * \mathrm{G} 3}=-0.69\end{array}$ & $\begin{array}{c}\mathrm{d}_{\mathrm{G} 1 * \mathrm{G} 2}=0.26 \\
\mathrm{~d}_{\mathrm{G} 1 * \mathrm{G} 3}=0.63 \\
\mathrm{~d}_{\mathrm{G} 2 * \mathrm{G} 3}=-0.40\end{array}$ & $\begin{array}{l}\mathrm{d}_{\mathrm{G} 1 * \mathrm{G} 2}=-0.16 \\
\mathrm{~d}_{\mathrm{G} 1 * \mathrm{G} 3}=-0.38 \\
\mathrm{~d}_{\mathrm{G} 2 * \mathrm{G} 3}=-0.23\end{array}$ & $\begin{array}{l}\mathrm{d}_{\mathrm{G} 1 * \mathrm{G} 2}=-0.11 \\
\mathrm{~d}_{\mathrm{G} 1 * \mathrm{G} 3}=-0.29 \\
\mathrm{~d}_{\mathrm{G} 2 * \mathrm{G} 3}=-0.20\end{array}$ \\
\hline
\end{tabular}

Note. $\mathrm{SA}=$ self-assessment; $\mathrm{COI}=$ Collecting Occupational Information; SPPI $=$ Search for Professional Practical Information; FP $=$ Future Planning; Conc $=$ Concern; Con. $=$ Control; Cur.= Curiosity; Conf.= Confidence

It is noted that all factors of the EAE-EP presented statistically significant results. When the Tukey test was performed, only for three factors differences between groups were observed. For self-evaluation, G3 differed from G1 and G2. In the Factors of Occupational Information Collection and Search for Professional Practical Information, G3 and G2 differed. In the case of the EAEEP factors, most of the differences were of medium effect, and for the Self-evaluation factor, the difference between G1 and G2 with $\mathrm{G} 3$ were the highest, respectively $\mathrm{d}=-0.86$ and $\mathrm{d}=-0.87$.

In the CAAS, only the Concern and Control factors presented significant results and differences between the groups when the Tukey test was performed. These differences occurred between the G3 and the G1 / G2 set for the Concern dimension, and G3 and G1 differed in the Control factor. The effect size was also observed, in which the majority was of medium effect, with the most significant value between G2 and G3 in the Concern factor $(d=-0.69)$. As a synthesis, it is worth mentioning that in the EAE-EP factors, the largest effect sizes were systematically in the differences between G2 and G3, that is, both groups that intend to do VG, but the group of those who have already decided and the group of those who are still undecided, respectively. In the CAAS, the largest effect sizes were between G1 and G3 in three factors, except Concern.

\section{Discussion}

This research aimed to verify the relationship between self-efficacy for professional choice and career adaptability, as well as to verify differences in these constructs between groups of adolescents who had or did not intend to undergo vocational guidance. It can be stated that the two hypotheses were at least partially corroborated, and then comments and reflections on the findings will be made.

In the results concerning the correlation between the instruments, it was possible to verify that, although all the factors of the instruments had a positive correlation, the highest coefficients were in 0.50 (in fact, all referring to the Self-evaluation factor of the EAE-EP), below the meta-analysis of Rudolph et al. (2017) presented (0.65 on average). The fact that the highest correlations were observed in the Self-assessment factor, especially that found with the Concern factor of the CAAS, seems coherent, since the self-assessment is basically focused on the evaluation that the individual performs on his or her own ability to choose a profession based on the knowledge of his or her characteristics, abilities and opinions (Ambiel \& Noronha, 2012) and the Concern dimension of the CAAS, involves the skills to reflect and plan his or her professional future (Savickas \& Porfeli, 2012). In this way, evaluating his or her beliefs, taking into account his or her characteristics and opinions, also helps the adolescents think about their career and prepare themselves to deal with likely challenges they may encounter.

The correlations found, although not as robust as that suggested by Rudolph et al. (2017), support Rossier's (2015) claim that both adaptability and self-efficacy play roles of mediating variables between personality traits and interests, 
understood as dispositional constructs, with effective vocational behaviors such as vocational exploration and the decision-making process itself. The logic presented by Rossier (2015) is that both career adaptability and selfefficacy for professional choice are personal strengths or competencies that inform the person about his or her condition to engage in and to deal with effective decisionmaking tasks. Thus, the correlation patterns found in this study corroborate the author and provide evidences that both constructs can be used together in the VG process.

Regarding the analyses of variance, it can be observed that interesting differences in the groups were observed. Among them, the trends observed particularly in each instrument stand out. In the EAE-EP, it was noted that, consistently, the largest effect sizes were observed among the groups that would like to undergo a VG, although in one group, they already had clarity about their decision (G2) and the other did not (G3). In the CAAS, with the exception of the Concern factor that followed the trend of the previous instrument, the largest differences were observed for the groups that already had absolute clarity of their decision, and therefore did not mention interest in doing VG (G1), of those not decided with need to go through the process (G3). In both instruments, the lowest scores have always been observed for G3. Therefore, it may be noted that, in this sample, lower levels of self-efficacy and adaptability are associated with indecision and with the need to do VG. Previous studies, such as Guan et al. (2009), Lassance, Bardagi and Teixeira (2009), Melo-Silva, Oliveira and Coelho (2002) and Ribeiro (2003) support the results found here, since they report that, on the one hand, better levels of self-efficacy tend to lead to better career outcomes and, on the other hand, interventions in the VG contribute precisely to raising vocational exploration and reducing indecision, characteristics inherent in G3 response.

Considering the general objective of this work, which is to relate the concepts of self-efficacy to professional choice and career adaptability and to investigate the possible differences between the groups of students formed from the intention or not to participate in a process of vocational guidance (VG), the results obtained were satisfactory and indicate that the instruments used can contribute to the practice in the field of the VG, since they will allow to identify potential users of services. Therefore, the evaluation of these tests, the process and the results for the VG, can collaborate with strategies directed to Brazilian high school students.

It is important to highlight that the evaluation of the constructs according to the data found in this study can be useful to guide the action of the advisers, to understand the beliefs of self-efficacy and the adaptive resources of those who are being guided throughout the work in the VG. In addition, the exploration of other variables such as interest, personality, among others, can favor the correlation with the respective constructs as a measure of process evaluation.

However, the significant correlations found were moderate, indicating that the constructs are distinct, although the relationshipsbetween themare coherentfrom the conceptual point of view (Ambiel \& Noronha, 2012; Savickas \& Porfeli, 2012).
It should be emphasized that, when considering self-efficacy for professional choice and career adaptability, the study was relevant, since there are no studies analyzing both with high school To conclude, the present article has some limitations, such as data collection was performed only in one public school in a single city in the interior of the state of São Paulo, which may not be representative for the public of Brazilian high school students. In addition, the fact that the research was transversal allows us to observe the differences between groups, but it does not allow affirming that G3 people sought more the VG service more than the other groups. Thus, in the future, research with an experimental design could be carried out, seeking to comprehend in a more comprehensive way the issue raised.

\section{References}

Ambiel, R. A. M. (2014). Adaptabilidade de carreira: Uma abordagem histórica de conceitos, modelos e teorias [Career adaptability: A historical approach of concepts, models and theories]. Revista Brasileira de Orientação Profissional, 15(1), 15-24. Retrieved from http://pepsic. bvsalud.org/pdf/rbop/v15n1/04.pdf

Ambiel, R. A. M. (2016). Avaliação psicológica em processos de orientação profissional e de carreira [Psychological assessment in career guidance and career processes]. In R. S. Levenfus (Org.), Orientação vocacional e de carreira em contextos clínicos e educativos [Vocational guidance and career in clinical and educational settings] (pp. 114-125). Porto Alegre, RS: Artmed.

Ambiel, R. A. M., \& Hernandéz, D. N. (2016). Relações entre autoeficácia para escolha profissional, exploração e indecisão vocacional. Revista Brasileira de Orientação Profissional, 17(1), 67-75. Retrieved from http://pepsic. bvsalud.org/pdf/rbop/v17n1/08.pdf

Ambiel, R. A. M., \& Noronha, A. P. P. (2012). Escala de autoeficácia para escolha profissional: Manual técnico [Self-efficacy scale for professional choice: Technical manual]. São Paulo, SP: Casa do Psicólogo.

Ambiel, R. A. M., \& Noronha, A. P. P. (2016). Professional choice self-efficacy: Predicting traits and personality profiles in high school students. Psicologia: Reflexão e Crítica, 29(1), 1-8. doi:10.1186/s41155-016-0021-0

Ambiel, R. A. M., Carvalho, L. F., Martins, G. H., \& Tofoli, L. (2016). Comparing the adaptabilities of Brazilian adolescent students and adult workers. Journal of Vocational Behavior, 94, 20-27. doi:10.1016/j. jvb.2016.02.005

Ambiel, R. A. M., Noronha, A. P. P., \& Carvalho, L. F. (2015). Analysis of the Professional Choice Self-Efficacy Scale using the Rasch-Andrich Rating Scale Model. International Journal for Educational and Vocational Guidance, 15(3), 205-219. doi:10.1007/s10775-0159293-7 
Araújo, L. C. P. (2003). Orientação profissional no ensino médio: Da concepção à prática [Professional guidance in high school: From concept to practice] (Dissertação de Mestrado). Retrieved from https://repositorio.ufpe.br/ bitstream/123456789/4803/1/arquivo5986_1.pdf

Audibert, A., \& Teixeira, M. A. P. (2015). Escala de adaptabilidade de carreira: Evidências de validade em universitários brasileiros [Career adapt-abilities scale: Evidences of validity in brazilian university students]. Revista Brasileira de Orientação Profissional, 16(1), 83-93. Retrieved from http:// pepsic.bvalud.org/scielo.php?script=sci arttext\&pid=S1679-33902015000100009

Bandura, A. (1977). Self-efficacy: Toward a unifying theory of behavioral change. Psychological Review, 84(2), 191215. 47. doi:10.1037/0033-295X.84.2.191

Betz, N. E., \& Luzzo, D. A. (1996). Career assessment and the career decision-making self-efficacy scale. Journal of Career Assessment, 4(4), 413-428. doi:10.1177/106907279600400405

Cardoso, P., Silva, J. R., Gonçalves, M. M., \& Duarte, M. E. (2014). Innovative moments and change in career construction counseling. Journal of Vocational Behavior, 84(1), 11-20. doi:10.1016/j.jvb.2013.10.001

Chiesa, R., Massei, F., \& Guglielmi, D. (2016). Career Decision-Making Self-Efficacy change in Italian high School students. Journal of Counseling \& Development, 94(2), 210-224. doi:10.1002/jcad.12077

Conselho Federal de Psicologia. (2003). Resolução CFP No. 07/2003. Institui o Manual de Elaboração de Documentos Escritos produzidos pelo psicólogo, decorrentes de avaliação psicológica e revoga a Resolução CFP No. 17/2002. Retrieved from http://site.cfp.org.br/wpcontent/uploads/2003/06/resolucao2003_7.pdf

Dancey, C. P., \& Reidy, J. (2006). Estatística sem matemática para psicologia: Usando SPSS para Windows [Statistics without mathematics to psychology: Using SPSS for Windows] (L. Viali, Trans.). Porto Alegre, RS: Artmed.

Di Fabio, A. (2016). Life design and career counseling innovative outcomes. The Career Development Quarterly, 64(1), 35-48. doi:10.1002/cdq.12039

Fan, J. (2016). The role of thinking styles in career decisionmaking self-efficacy among university students. Thinking Skills and Creativity, 20, 63-73. doi:10.1016/j. tsc.2016.03.001

Ginevra, M. C., Pallini, S., Vecchio, G. M., Nota, L., \& Soresi, S. (2016). Future orientation and attitudes mediate career adaptability and decidedness. Journal of Vocational Behavior, 95-96, 102-110. doi:10.1016/j.jvb.2016.08.003
Guan, Y., Deng, H., Sun, Y., Wang, Y., Cai, Z., Ye, L., ... Li, Y. (2013). Career adaptability, job search self-efficacy and outcomes: A three-wave investigation among Chinese university graduates. Journal of Vocational Behavior, 83(3), 561-570. doi:10.1016/j.jvb.2013.09.003

Hacket, G., \& Betz, N. E. (1981). A self-efficacy approach to the career development of women. Journal of Vocational Behavior, 18(3), 326-336. doi:10.1016/00018791(81)90019-1

Lassance, M. C. P., Bardagi, M. P., \& Teixeira, M. A. P. (2009). Avaliação de uma intervenção cognitivoevolutiva em orientação professional com um grupo de adolescentes brasileiros [Evaluation of a cognitiveevolutive vocational guidance intervention with a group of Brazilian adolescents]. Revista Brasileira de Orientação Profissional, 10(1), 23-32. Retrieved from http://pepsic.bvsalud.org/scielo.php?script=sci_ arttext\&pid=S1679-33902009000100005

Lent, R. W., Brown, S. D., \& Hackett, G. (1994). Towards a unifying social cognitive theory of career and academic interests, choice and performance. Journal of Vocational Behavior, 45(1), 79-122. doi:10.1006/jvbe.1994.1027

Maree, J. G. (2015). Career construction counseling: A thematic analysis of outcomes for four clients. Journal of Vocational Behavior, 86, 1-9. doi:10.1016/j. jvb.2014.10.001

Masdonati, J., Perdrix, S., Massoudi, K., \& Rossier, J. (2014). Working alliance as a moderator and a mediator o career counseling effectiveness. Journal of Career Assessment, 22(1), 3-17. doi:10.1177/1069072713487489

Melo-Silva, L. L., Oliveira, J. C., \& Coelho, R. S. (2002). Avaliação da orientação profissional no desenvolvimento da maturidade na escolha da profissão [Vocational guidance assessment in the development of maturity in the choice of profession]. Psic: Revista da Vetor Editora, 3(2), 44-53. Retrieved from http://pepsic.bvsalud.org/scielo.php?script=sci arttext\&pid=S1676-73142002000200006

Noronha, A. P. P., Freitas, P. C. S., Piovezan, N. M., \& Azevedo, M. C. R. (2013). Afetos positivos e negativos e autoeficácia em jovens do ensino médio [Negative and positive affects and self-efficacy of high shool students]. Revista de Psicología, 15(1), 9-21. Retrieved from http://revistas.ucv.edu.pe/index.php/R_PSI/article/ viewFile/206/117

Pajares, F., \& Olaz, F. (2008). Teoria social cognitiva e autoeficácia: Uma visão geral [Social cognitive theory and self-efficacy: An overview]. In A. Bandura, R. G. Azzi, S. Polydoro (Orgs.), Teoria social cognitiva: Conceitos básicos [Social cognitive theory: Basic concepts] (pp. 97-114). Porto Alegre, RS: Artmed. 
Pasian, S. R., Melo-Silva, L. L., \& Okino, E. T. K. (2015). Avaliação psicológica em Orientação Profissional e de Carreira no Brasil: Instrumentos disponíveis e evidências empíricas [Psychological assessment in vocational guidance and career in Brazil: Available tools and empirical evidence]. In S. M. Barroso, F. ScorsoliniComin, \& E. Nascimento (Orgs), Avaliação psicológica: Da teoria às aplicações [Psychological assessment: From theory applications] (pp. 305-332). Petrópolis, RJ: Vozes.

Ribeiro, M. A. (2003). Demandas em orientação profissional: Um estudo exploratório em escolas públicas. Revista Brasileira de Orientação Profissional, 4(1-2), 141-151. Retrieved from http://pepsic.bvsalud.org/pdf/rbop/v4n12/v4n1-2a12.pdf

Rossier, J. (2015). Career adaptability and life designing. In L. Nota \& J. Rossier (Eds.), Handbook of life design: From practice to theory and from theory to practice (pp. 153-168). Boston, MA: Hogreffe.

Rudolph, C. W., Lavigne, K. N., \& Zacher, H. (2017). Career adaptability: A meta-analysis of relationships with measures of adaptivity, adapting responses, and adaptation results. Journal of Vocational Behavior, 98, 17-34 . doi:10.1016/j.jvb.2016.09.002

Savickas, M. L. (1997). Career adaptability: An integrative construct for life-span, life-space theory. The Career Development Quarterly, 45(3), 247-259. doi:10.1002/j.2161-0045.1997.tb00469.x

Savickas, M. L., \& Porfeli, E. J. (2012). The Career Adapt-Abilities Scale: Construction, reliability, and measurement equivalence across 13 countries. Journal of Vocational Behavior, 80(3), 661-673. doi:10.1016/j. jvb.2012.01.011

Super, D. E., \& Knasel, E. G. (1981). Career development in adulthood: Some theoretical problems and a possible solution. British Journal of Guidance \& Counselling, 9(2), 194-201. doi:10.1080/03069888108258214

Taylor, K. M., \& Betz, N. E. (1983). Applications of selfefficacy theory to the understanding and treatment of career indecision. Journal of Vocational Behavior, 22(1), 63-81. doi:10.1016/0001-8791(83)90006-4

Teixeira, M. A. P., Bardagi, M. P., Lassance, M. C. P., Magalhães, M. O., \& Duarte, M. E. (2012). Career Adapt-Abilities Scale - Brazilian Form: Psychometric properties and relationships to personality. Journal of Vocational Behavior, 80(3), 680-685. doi:10.1016/j. jvb.2012.01.007

Van Vianen, A. E. M., Klehe, U. C., Koen, J., \& Dries, N. (2012). Career Adapt-Abilities Scale-Netherlands form: Psychometric properties and relationships to ability, personality, and regulatory focus. Journal of Vocational Behavior, 80(3), 716-724. doi:10.1016/j.jvb.2012.01.002
Ventura, C. D., \& Noronha, A. P. P. (2014). Autoeficácia para escolha profissional, suporte familiar e estilos parentais em adolescentes [Career choice self-efficacy, family support and parenting styles in adolescents]. Avaliação Psicológica, 13(3), 317-324. Retrieved from http://pepsic.bvsalud.org/scielo.php?script=sci arttext\&pid=S1677-04712014000300003

Whiston, S. C., Rossier, J., Barón, P. M. H. (2015). The Working Alliance in Career Counseling: A Systematic Overview. Journal of Career Assessment, 24(4), 591604. doi:10.1177/1069072715615849

Zacher, H., Ambiel, R. A. M., \& Noronha, A. P. P. (2015). Career adaptability and career entrenchment. Journal of Vocational Behavior, 88, 164173. doi:10.1016/j.jvb.2015.03.006

Rodolfo Augusto Matteo Ambiel is a Professor of the Universidade São Francisco, Campinas-SP, Brazil.

Thaline da Cunha Moreira is Master in Psychology by the Universidade São Francisco, Campinas-SP, Brazil.

Dianniffer Aparecida Oliveira is a Master in Psychology by the Universidade São Francisco, Campinas-SP, Brazil.

Edson Cardoso Pereira is a Master in Psychology by the Universidade São Francisco, Campinas-SP, Brazil.

Débora Noemi Hernandez is a Psychologist by Universidade São Francisco, Campinas-SP, Brazil.

Authors' Contribution:

All authors made substantial contributions to the conception and design of this study, to data analysis and interpretation, and to the manuscript revision and approval of the final version. All the authors assume public responsability for content of the manuscript.

Received: Oct. 26, 2016

1st Revision: Feb. 24, 2017

2nd Revision: Jun. 16, 2017

Approved: Oct. 31, 2017

How to cite this article:

Ambiel, R. A. M., Moreira, T. C., Oliveira, D. A., Pereira, E. C., \& Hernandez, D. N. (2018). Self-Efficacy, adaptability and intention of searching for vocational guidance in adolescents. Paidéia (Ribeirão Preto), 28, e2840. doi:http://dx.doi.org/10.1590/1982-4327e2840 